\title{
"I (can) see myself... But what for?" On Live Camera Feeds in Courtrooms (from the Perspective of Witnesses)
}

\author{
Michał Dudek ${ }^{1}$ [ Mateusz Stępień ${ }^{1}$ (i)
}

Published online: 3 June 2019

(c) The Author(s) 2019

\begin{abstract}
The paper's aim is to present and critically discuss a peculiar practice noticed and studied in courtrooms in the Lower Court in Kraków, Poland. In courtrooms where different hearings take place, two cameras are installed on the wall or on the stand near the judge's bench. One camera is aimed at the center of the courtroom, where non-professional participants such as witnesses or plaintiffs stand while being questioned by judge. The second camera's view is more general-it covers the rest of the courtroom, including the benches for plaintiffs, claimants, defendants, and their legal representatives, and most notably the general public. Naturally, the mere presence of cameras in the modern courtroom is not surprising. What raises some questions is the presence of TV screens in the Kraków Lower Court's courtrooms (and in Poland's courts in general), which display the feed from both cameras during the hearing. Consequently, people gathered in the courtroom, especially people questioned by the judge (such as witnesses), can see themselves "live" in the TV screen. Even without raising the subtle details and differences between individual courtrooms, the system of displaying, in real time, live video feeds from a courtroom into the same courtroom begs for more detailed, critical analysis. For instance, one should address the system's (presumably intended) functions (e.g. transparency, behavior control, and correction of time perception) and the real consequences for the dynamics during hearings, which are not assumptions or hypotheticals. The paper distinguishes the issues connected with the system and addressees them through the perspective of witnesses who participate in the hearings, using the collected opinions of witnesses.
\end{abstract}

Keywords Courtroom · Live feed camera display · Witnesses · Observations · Interviews

Michał Dudek

michal.dudek@uj.edu.pl

Mateusz Stępień

mateusz.stepien@uj.edu.pl

1 Department of Sociology of Law, Faculty of Law and Administration, Jagiellonian University in Krakow, Bracka 12, Room 214, 31-005 Kraków, Poland 


\section{Introduction}

The aim of this paper is to present and critically discuss a peculiar practice noticed in courtrooms in the Lower Court in Kraków, Poland, especially from the perspective of witnesses summoned to the case hearings, who can experience it. The word "peculiar" is used because other research projects can determine whether a similar practice is noticeable in courtrooms in other countries. Future discussions of this paper could shed some light on the issue. However, as will be demonstrated below, the literature review justifies the hypothesis that the practice analyzed here is either absent in other jurisdictions or is simply ignored, even if it is present.

Polish lower (or regional) courts are courts of the first instance and consequently handle most of the cases, with the exception of some categories where first instance trials are held in higher courts in the national judicial system. The subject of analysis is that in Kraków's Lower Court, two cameras are installed, on the wall or on the stand near the judge's bench, in some courtrooms where hearings in different cases (especially criminal, civil and offense) take place. One camera points at the center of the courtroom where non-professional participants, especially witnesses, stand while being questioned by the judge. One has to remember that Polish court hearings are in most cases based on the inquisitorial, not adversarial, model of proceedings, and the judge therefore plays a much more active role and questions witnesses by him or herself (see [3]). The second camera's view is much more general. This camera covers the rest of the courtroom, most notably benches for the general public. It also covers the benches for plaintiffs, claimants, defendants, and their legal representatives. However, there are no cameras which cover the judge. Of course, the mere presence of cameras in the courtroom is not surprising. The issue that raises questions is that in Kraków's Lower Court courtrooms there are large TV screens, which display the two cameras' feed during hearings. It leads to a situation where the people gathered in the courtroom, most notably those being questioned by the judge, can see themselves "live" on the television screen (see Fig. 1; see also [11, 19, 36, 41]). It not only seems to function as a specific mirror, but also as a timer, because it also displays the running time from the beginning of the hearing (or to be more precise, from the time the clerk switches the whole system on). Naturally, the audio and video of the hearing is recorded and can be accessed by the participants to a given case, most notably the parties' legal representatives, through dedicated software and databases. Legal representatives can access the audio recording through their accounts in a dedicated information system. The video recording is only accessible in the court building's dedicated room. Even though the following paragraphs refer to the system's functioning and its perception by witnesses who frequent courtrooms in Kraków's Lower Court, one has to stress that the system is in fact implemented nation-wide. It is up to future studies to compare the system's functioning and perceptions in Kraków's Lower Court with Poland's other courts.

It seems appropriate to highlight the originality of the system in comparison to other instances where the literature mentions cameras and televisions being 


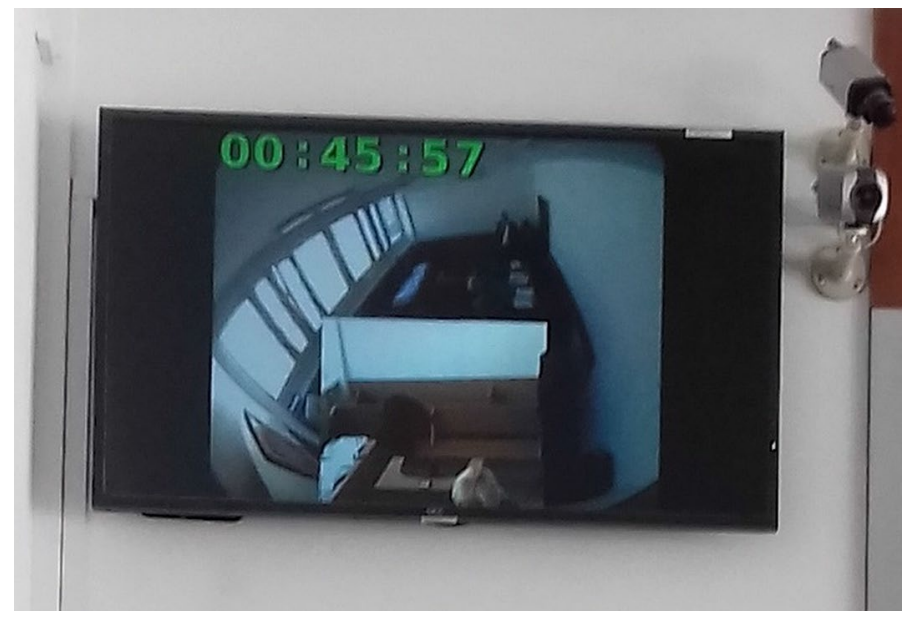

Fig. 1 The system as exemplified in one of the courtrooms in Kraków's Lower Court

present in the courtroom. For over half a century, the issue of cameras in the courtroom has received significant interest and coverage from many scholars and officials, especially in the United States [1, 2, 5-8, 14-16, 21-23, 26-28, 31, 35, 37, 42, 43, 46, 47, 49, 52]. One should also not neglect other countries, such as China with its relatively recent practice of broadcasting case hearings live or making video libraries of past hearings [30, 44]. Various research projects were proposed and some empirical studies, concerning the impact of such technology on proceedings and its participants, were conducted. Next to such a social-scientific approach, jurists (academics, practicing lawyers, and judges) took considerable time to analyze the pros and cons of allowing cameras in courtrooms from a plethora of perspectives. Moreover, even the noticeably suspicious, if not simply negative, attitude of some judges towards the issue in question became its own subject of research. Even though, there is widespread interest in cameras, it is still focused - to a large extent-on cameras that in a way come from the outside of the courtroom, from journalists and reporters, representatives of the news industry. The presence of cameras that are built in the courtrooms and are part of the court's infrastructure is seldom discussed. However, it is not the most important conclusion of the literature review. One cannot find any reference to a similar system. Literature on "cameras in the courtroom" says nothing about courtroom cameras combined with TV screens, which display the live feed from the cameras to the participants during a hearing. This paper is meant to be a first step in filling this particular gap.

The paper's aim is to try to reconstruct and critically examine the witnesses' understanding of the system, based on their own opinions. The discussed solution can be assessed from a plethora of perspectives. The witnesses' perspective was chosen because in most cases, the witness can be the most influenced by the courtroom's live camera feed. This is because one of the cameras is pointed directly at the witness stand, and the television screen's live display is the most visible for the 
witnesses. Additional questions could be raised, for example, on the real impact of the live feed on courtroom dynamics or on the formation of general attitudes towards the courts. Nevertheless, this paper has a much narrower scope-to try to establish whether witnesses notice the cameras and the live feed streaming on the television screens and, if so, how they understand the practice and what they think of it. It is important to understand how (mostly) lay participants interpret the practice in question (if they notice it at all), because of, for example, the possibility of cognitive overload or activation of some cultural schemata related to the act of "monitoring/ being under surveillance". It is crucial to analyze this practice not only in a purely theoretical way, but also by referring to the opinions of people actually immersed in this particular situation, whose perspective of the hearing and courtroom can be quite different from a researchers' viewpoint. Moreover, looking at the practice from the witnesses' perspective can lead to a more comprehensive understanding of the phenomenon. Understanding the witnesses' viewpoint is meant as a way to obtain perspectives of the practice, in larger numbers than researchers alone would be able to come up with.

\section{Context of Research and Adopted Approach}

The interest in this particular system was developed coincidentally. Namely, the system was noticed in the course of a large research project which took place from 2016 to 2019. The project addressed the phenomenon of power distance in the courtroom, especially between judges and witnesses. As mentioned earlier, judges have a very active role in the Polish legal system, because they question witnesses during hearings. Put simply, the project's aim was to determine how power distance, established mostly by the judge's verbal and nonverbal behaviors towards witnesses, influenced the witnesses' satisfaction from the hearing. The project's methodology involved simply (or "simply") visiting court hearings in Kraków's Lower Court where witnesses were present. One member of the research team observed the whole hearing, using a specific questionnaire, and took notes on the verbal and nonverbal behaviors of the judges, witnesses, and other participants. The emphasis was on the ways the judge managed the hearing, for example, whether he or she was strict, formalistic or welcoming, and how he or she dictated the witness's paraphrased statements to the clerk. The courtroom's appearance was also assessed. At the same time, the other member of the research team stayed outside the courtroom being observed and waited with the interview questionnaire for the witness who had just been questioned. Naturally, both researchers communicated with each other using the Short Message Service (SMS). When the witness left the courtroom, the interviewer approached him or her and asked whether he or she would be agreeable to discuss the hearing.

Most of the questions in the questionnaire concerned the behavior of judges: how he or she was perceived by the witness; what was positive or negative about the judge's behavior; and whether there was something missing in the judge's behavior. However, the researchers were intrigued by the cameras and television screen with the live feed, and decided to take the opportunity to include questions about 
the system. Where the television screen had been switched on with a live feed, witnesses were asked whether they had noticed the screening of the hearing on the television, and their views if they had. Where the cameras and television screen were in the courtroom but the display had not been switched on, witnesses were asked whether they had noticed the television screen with cameras, and their views if they had. All the answers were written down and analyzed.

The witnesses were questioned about the system in order to obtain a preliminary estimate of the possible impact of cameras, television screens, and live feeds on witnesses, based on their opinions. As will be demonstrated, their opinions often addressed aspects of the system that the researchers had not anticipated, even though the researchers had taken considerable time to think about and discuss the system. On the other hand, the witnesses also did not acknowledge some aspects of the system which had been noticed by the researchers. In total, the empirical research conducted and discussion of the system presented in this paper, contrasting the opinions of the witnesses and researchers with each other, reaches a more comprehensive understanding of the practice in question.

In other words, the presented paper can be regarded as a study in empirical semiotics (on empirical semiotics, see, for e.g., $[12,38]$ ). The question "what the system means to witnesses?" was not addressed in purely theoretical, hypothetical way, but with the use of interview method (other instance of its use in semiotic research, see, for e.g., [17]), combined with passive observation method. Even though the combination of both methods did not provide a thorough empirically-grounded explanation concerning the meaning production process (answer to question "why witnesses understand the system the way they do?"), but it still gave a significant glimpse into the witnesses' meaning production results, which hitherto were simply unknown.

The more subtle details and differences between particular courtrooms and the live camera feeds in them should be addressed before the witnesses' opinions are presented and discussed in light of the other perspectives which come to mind, such as the purposes of the system that can be safely assumed, or ideas about the consequences for the dynamics during court hearings.

\section{Some Technical Observations}

The system of live feeds from cameras in the courtroom goes by the name of the ReCourt Project [25]. Occasionally, research team members observed the ReCourt Project logo appearing at random intervals in the live feed during the hearings. There were also attempts to gather information from the system's creators, but the project's website seems to be dedicated only for system's users to $\log$ in. However, the Polish Ministry of Justice website has a freely downloadable record player with a user manual, which is dedicated to display the recorded hearings [39]. Moreover, one still can obtain original official documents from the Polish Ministry of Justice concerning the issue in question, such as the system's technical requirements, which were prepared for the sake of public procurement procedures [10]. Unfortunately, one cannot obtain more official statements about the goals or effects of the live camera feeds in courtrooms, not to mention any 
information regarding whether a pre-implementation assessment was conducted. Popular media coverage (e.g. [32, 34, 40, 50]), or accessible Internet discussions (e.g. [51]), also do not answer the questions that come to mind when confronted with the system. From this perspective, this study can be regarded as filling a noticeable gap with respect to the practice in question.

Even though there is only one provider of the service, the system is not used and does not work in the same way across different courtrooms, even if they are in the same court building. During the observations, the following differences were observed:

- not all the courtrooms had the system installed. What was particularly strange was that Kraków's Lower Court building in fact consists of two buildings-an older building with significantly smaller and visually unappealing courtrooms where the system was used, and the so-called L-wing new building which was visually and architecturally different, and more visually appealing and elegant. However, the system was not installed in courtrooms in the L-wing;

- some displays had poor color contrast, in that the bright, white parts of the courtroom were visible, while parts of the courtroom which were not white were less visible. In some cases, the poor display meant that it was difficult to recognize oneself in the television screen;

- also referring to camera technicalities, some of the cameras, especially those that captured the whole courtroom, seemed to have fisheye lenses. In smaller courtrooms, this was questionable as they made the courtroom appear to be substantially larger than it actually was;

- there was a noticeable delay between the actions taking place during the hearing and their appearance on the television screen;

- additionally, the way in which feeds from two cameras were displayed on one television screen was not the same in different courtrooms. The feed from the camera capturing the whole courtroom was used as a background for the display from the second camera, which was focused on the witness. However, this second feed was placed either at the bottom center of the first feed, or at the left or right bottom corner of the screen;

- not all the television screens were placed on the wall in the corner of the courtroom. Some screens were installed on a moveable stand. Moreover, there was no particular corner of the courtroom where the screens were installedsome were placed on the courtroom's right or the left side (from the perspective of the public benches, which were across the judge's bench);

- there were instances where the television screen was not switched on, but cameras were recording (according to the judges' remarks). In other cases, both the television and cameras were switched off. A peculiar situation was also observed where the television screen displayed the still shot of an empty courtroom, instead of the hearing that was occurring in the same room;

- finally, there were no cameras which captured the judge. The judge was simply absent from the display and visual recording (audio was recorded). 
It is worth emphasizing again that in one court building, the same system by one provider in different courtrooms works differently. The differences can be regarded as a keyword when one addresses the following issues: the explanation for the system where people can see themselves "live" on the television screen during a case hearing; and the impact of the system on the people in the courtroom, especially the witnesses. To try to address these issues, one should first present the witnesses' opinions, before moving to a more detailed discussion, which will also take into account ideas on the system other than those advanced by the witnesses.

\section{Opinions of the Witnesses}

When the system was noticed in Kraków's Lower Court, researchers started to think about it and try to find ways to explain it. They wanted to answer the question of why it is used and what its main purpose or purposes are. A decision was made to make use of the opportunity of the existing research being conducted in Kraków's Lower Court, and observe the witnesses' opinions on the live camera feeds. Witnesses were chosen, because they are distinguished by having a separate camera focused on the location in the courtroom where they stand while being questioned by the judge. Conducting interviews with witnesses was a demanding task for a variety of reasons: some witnesses left without speaking after they left the courtroom; some refused to talk; some did not appear in court; hearings were postponed; or witnesses were accompanied by such a large number of people that a conversation in the court's narrow corridors became inconvenient. Ultimately, a small number of witnesses agreed to be interviewed. Their statements often added to the initial thoughts about the system, that had been generated before speaking with the witnesses. This section presents the statements collected from the witnesses, before discussing the issues raised by them.

For clarification, the observations and interviews were conducted from the beginning of January to the beginning of July 2018. For nearly every week during that period, research team members (two pairs, each consisting of a researcher observing and a researcher interviewing) visited Kraków's Lower Court at least once a week to observe courtrooms during hearings and interview witnesses. The latter task was difficult, but not only because of the abovementioned reasons. There were instances where a witness had been successfully approached and the interview had started, but it was unfortunately interrupted and the question about the cameras was not asked. Even though the list of statements about the system is not impressive in terms of the numbers collected (40 interviews where a relevant question was asked and answered), one has to recall that research team members approached a larger number of witnesses, not to mention the number of courtroom observations. Consequently, collecting 40 statements was already a demanding task and can be considered as a success.

One should also stress that there were also courtrooms in the L-wing that were not equipped with the entire system, as they only had cameras, but did not have television screens displaying the cameras' live feed. Nevertheless, the interviewers still asked those witnesses, who had testified in the L-wing courtrooms, about 
the presence of cameras and television screens in the courtrooms. The following is a list of the statements (hereinafter, all dates refer to 2018), quoted verbatim:

1. man, January 15- "It's OK. Later one can play some important moments, in case someone would deny that something was different";

2. man, January 26-did not notice and was in a hurry;

3. man, February 8-did not notice and added "but supposedly all proceedings are recorded now";

4. woman, February 8-did not notice "because everything was so fast";

5. man, February 8-witness said "it lasted too short to notice anything", but after some time he went back to the issue of cameras and television screens, and said that they are occasionally too visible. He added that "it is better with recording because one can see person's behavior";

6. woman, February 16-did not notice and said that she spent her time looking at the judge, although there was one instance where she looked at the clerk;

7. woman, February 16-did not notice, but said that she saw the clerk writing;

8. man, March 8- "if I lied, then it's obvious [that I am against the system], but I did not have reasons to lie and then hide it that I've said something different";

9. woman, March 8- "I did not have problem with it [the system] so far it is only for the use of court, but if it would be somehow distributed, then no";

10. man, March 26-[about the system] "it would not bother [me]";

11. man, April 12 - "supposedly, today there was no recording";

12. woman, April 16 - approved and also said that "recordings are used in between cases so there is no doubt about who said what and when - there's recording, disc, end of story";

13. woman, May 29-“[The recordings] should be made public, so people could see how judges are behaving".

As stated above, there were also instances where the television screen was present but switched off for various reasons, which were most probably technical ones, but went unmentioned by the judge. In this situation, the witnesses were asked the following question: "did you notice the TV screen with cameras in the corner of the courtroom and, if so, what do you think about it?":

14. woman, February 2 - did not notice and said "if it [the system] was there and [I] would know about it, then [for me] definitely worse, stressful, unless [I] would be unaware";

15. man, February 2- “yes, I saw, I do not know whether they recorded or not. For me it does not make difference, because one still says what one knows, speaks the truth";

16. man, February 7-noticed and responded positively without any explanation, but also admitted that he did not pay attention to it;

17. man, February 7-did not notice and did not express any opinion on it;

18. woman, April 16 - did not notice the cameras and television screen and did not comment on the matter in any way; 
19. man, April 16 - an identical answer as that provided by the witness 18 .

There was one instance when the television screen was switched on, but it only displayed a still image of an empty courtroom, not the hearing itself:

20. man, April 19- “No, I guess not, there was no recording. However, it [recording] is not generally distracting, but there could be as well no TV screen at all, because it can distract someone. Cameras are just fine".

Fortunately, there were many cases where the system was present and working as intended-a television screen displaying the live feed from two cameras. In this situation, the question asked was as follows: "did you notice the presentation of recorded hearing in the TV screen in the corner of the courtroom and, if so, what do you think about it?":

21. man, January 10- “yes, I saw, judge also informed about it. Good, it is some kind of a document, in case someone has some doubts about judge's attitude, that she or he was one-sided, rude, or something. Let them record, good";

22. man, January 11 -noticed, but was afraid that it would be impossible for a witness to obtain the recording and criticized it because "someone's own medical documentation is available";

23. man, January 11- "yes [noticed], security matters [without any specification]";

24. man, January 11- “yes, I saw", "it's good, because often one is lying", "they [judges] are becoming more objective", narrative about the judges in the past"sometimes it happened that judge took care of interests of few, one party";

25. man, January 15- "I saw, but I am not embarrassed. I was in front of cameras before";

26. man, January 15 - did not notice;

27. woman, January 19- "good, everything is clear ('black on white')";

28. woman, January 19- “yes, I saw. The judge informed me about it at the beginning. They are making the stress bigger. And if it is recording, if someone says something wrong, can it be corrected later?";

29. woman, January 25-“yes, but I wasn't nervous, I had somewhere to look at";

30. man, January 25-“yes, I saw. It distracts, because I see myself. At least, it distracts me";

31. woman, January 26- “yes, I saw. Obviously, while I was listening I was looking, but while I was speaking it was like they weren't there [cameras and TV screen]. If I wanted, I looked, obviously. They do not worry me... good, because always one can come back to check who said what";

32. woman, February 21- “it's OK, because they do not have to write down this much";

33. man, February 21- "yes, the judge pointed at the screen while informing about the recording", when asked by interviewer "what is it for?"- "to reconstruct witnesses' testimonies", "audio is not enough?"-_no, what is happening [not only what is said] is important"; 
34. man, March 15- "it's OK, one can go back to the conversation";

35. man, March 23 - "I noticed. It does not make a difference to me. I am recorded all the time";

36. woman, March 23-did not notice;

37. man, April 5- "I did not notice, but I guessed that they are there";

38. man, April 12- "There was a TV screen; it did not bother";

39. man, April 24- "It was not bothering, I was not paying attention, I was focusing on the judge to understand better";

40. woman, May 29-did not notice.

\section{Providing Background for Discussion on Witnesses' Opinions}

As one can see, the system was certainly noticeable, even for witnesses who as laypersons would usually be in the court for the first time in their lives and would be stressed by the visit. The witnesses who noticed and expressed an opinion about the system often had a perspective which ultimately differed from that of researchers. The following paragraphs in this section describe the latter's views of the live camera feeds.

As stated above, audio-visual recordings of proceedings are available for legal representatives and can be regarded as assistance for a possible appeal. The recordings can be deemed as material which the legal representatives can refer to in their advocacy for their clients' interests. In the case of an appeal on the grounds of the judge's misconduct, there is a substantial difference between audio recordings of the judge's actions and audio-visual recordings. The latter can strengthen argumentation more than the former. However, the placement of cameras is such that the judge is absent from the video recording. Nevertheless, audio and video recordings of the proceedings can undoubtedly be used by legal representatives for their arguments on appeal. However, this benefit does not explain why the cameras' live feed is displayed during the hearing itself. One has to distinguish then between the effects of the live feed and the recording as a documentation of the completed hearing.

The issue of assistance in a possible appeal is naturally centered on the legal representatives, but there are also general explanations for the system which address parties other than the professional lawyers. First of all, live camera feeds can enhance or signal transparency, which in turn can increase the legitimacy of legal proceedings (on transparency in the legal context and its relationship with other important aspects of the legal system, see [4] and the literature cited there). The public, lawyers, judges, witnesses, and parties to the case can see the recordings real time with their own eyes and do not have to rely only on the words "the proceedings are recorded". People can see that the proceedings are recorded and specifically observed. They also know the way the proceedings look like through the camera lenses and in the recorded material, which can be used later. These benefits occur when the system is working properly, without any of the technical issues which were suggested earlier. Nevertheless, there is a straightforward message from a functioning camera feed: the proceedings are transparent, no element of the hearing is hidden, and everything can be scrutinized. In other words, next to 
a transparency-enhancing or signaling function, the system also has a legitimizing function.

A similarly wide group of people can benefit from the system's security-enhancing function. Courtroom hearings can be dynamic and it is wise to address some unfortunate, dangerous, or aggressive behaviors that can occur in the courtroom. Naturally, the probability of such dangerous accidents is already reduced, by a certain extent, by the metal detectors at the court's entrance and x-ray devices examining visitors' personal belongings. However, these devices do not examine the belongings of lawyers who show security workers their documents and are let in without the usual examinations, as observed in Kraków's Lower Court. Other security factors include the inherent seriousness of court proceedings, which can still be threatened or destroyed by participants' actions; the sublime nature of the courtroom (if it is built and designed such that its appearance alone informs people entering the courtroom that they are in a special, not an ordinary, place); the judges' outfits (e.g. in Poland even judges in lower courts are dressed in specific robes, unlike their counterparts in Sweden, see [9]); or the presence of uniformed police officers (occasionally present during proceedings if there are arrested criminals, or generally present in the court building). Cameras with their live feeds on television screens can enhance this security by a certain extent or enhance the subjective sense of security, but not the actual security. Ultimately, some accidents may occur even if the system is functioning perfectly. In such cases however, the recording is still useful for evidentiary purposes.

There is another possible purpose of live camera feeds in courtrooms, which is closely connected to the effect of enhancing security (or the sense thereof). Namely, the live feeds are displayed during the proceedings such that the participants, especially witnesses, can see themselves on the screen. This could be an incentive for the witnesses to control their behavior and exercise self-discipline. A misbehaving witness does not have to wait to be reprimanded, because he or she can keep an eye on himself or herself throughout the questioning. The witness can see, through his or her own eyes, aspects of his or her behavior that require some adjustments and make them, or it can lead to a specific kind of cognitive dissonance (seeing oneself behaving not in the way one actually wants). Moreover, the witnesses can not only see themselves, but also the perception of the more powerful individuals in the courtroom. The system enables better self-control, but also specifically reminds the witness that his or her behavior is, or at least can be, recorded and seen by a person in power. It is fairly clear and transparent that the witness is under surveillance. It can be made even clearer by the judge, who can point out at the hearing's beginning that it is recorded. The judge can also point at the cameras and television screen. However, the way such recordings can be used after the hearing is unclear and far from transparent, especially from the perspective of lay witnesses. It is thus somewhat similar to Michel Foucault's Panopticon and (self-) disciplinary power mechanisms [13].

One can also say that the system is to a certain extent analogous to showing dance course participants a video recording of their practices, to increase their awareness of the errors they are making. One could attempt to correct another person's behavior verbally, but such interventions often can have negative side 
effects. If a dance instructor does not clearly show their students their errors, the students might not understand what the instructor is saying. In such cases, the participants are not only kept in the dark, but it is also easy to become irritated, which definitely does not help the learning process. Similarly, judges can verbally point out inadequacies in behavior in the courtroom, but some witnesses may regard these comments as aggressive, dominating, or antagonizing-labeling that is not necessarily valuable in the emotion-filled courtroom.

Consequently, making it possible for participants to glimpse themselves on the television screen can increase their awareness of their role in the novel (for them) and serious institutional setting. They can control their actions more vigilantly and the judge thus does not have reason to critically address their behavior. This is important because a judge's critical remarks can be regarded as a sign of the judge's lack of impartiality. A judge's actions, which are aimed at ensuring order in the courtroom, are often perfectly justified. Nevertheless, they can still be instrumentalized by being used to raise doubts about whether legal standards had been met during the proceedings. One could say then that live camera feeds reduce the need for judges to worry. However, it should be emphasized that the system's ability to encourage self-control will only work for some of the participants. It cannot be ruled out that there are and will be instances when people who can see themselves on the live camera feeds still behave improperly, because of their background or strong emotions.

There is also a potentially more subtle consequence of live camera feeds. Depending on the witness's personality traits, some witnesses can become overwhelmed by the experience not just of being questioned by the judge and the other participants, but also of being recorded and being able to see herself or himself on the television screen. Some witnesses are stressed by the mere act of speaking in public. It can be even more stressful to watch themselves speak or be questioned, because they are more self-aware and are trying not to make a fool of themselves before other people in a serious setting. It also cannot be ruled out that some witnesses, due to their personality, can react to the system completely differently. Whether justified or not, their self-confidence can be increased by being able to see themselves "live".

Another possible purpose of the system is to similarly increase the awareness of the hearing's participants. In this case, their increased awareness is not of their own appearance and behavior before the judge and other participants, but of the passage of time (on time and courtrooms, see, for e.g., [48]). The television screens display not only the camera feeds, but also the running time from the beginning of the hearing. Participants can simply look at the television screen to check the amount of time that had passed since the beginning of the hearing or when they started being questioned. One may assume that for lay participants who may be in the courtroom for the first time in their life, time in the courtroom passes slowly. One reason is that stress can cause them to perceive the events in the courtroom and their participation as taking a long time. If this perception is not corrected, it is possible that people leaving the courtroom would have a more negative opinion on the events, for reasons including their belief that it took a long time. Live camera feeds displayed on the television screen with a timer can correct such misperceptions. However, as will 
be demonstrated later, in the witness interviews there were no statements which substantiated this hypothesis.

Naturally, one could address the presence of timer on the television screen completely differently. Namely, one could say that the timer is meant for legal professionals who can review the recorded hearings, and the timer is simply a way for them to orientate themselves with the recorded data. However, that would be the case only if, for some reason, the software used to display recorded hearings did not show the time of the recordings. That is why it is safe to assume that the timer is meant for those who may experience the passage of time during a hearing differently from the passage of time in the "outside world". However, this hypothesis cannot be proven, because of the abovementioned lack of a thorough official explanation of the system from its creators or implementors.

\section{Discussing the Witnesses' Opinions}

In light of the above, it should be obvious that it is possible to discuss the system in the following terms: as a tool for security and disciplining the witnesses, as assistance for professional representatives, as a way to enhance transparency, or as a way to maximize the chances that the rules of procedure will be obeyed. However, at this point one should cease further speculation and refer instead to the witnesses' statements. Naturally, the following paragraphs in this section contain the interpretation of the collected data, prepared from the perspective of research team members and their experiences in conducting observations and interviews. The comments below are accompanied by references to specific statements from the witnesses, which were presented in Sect. 4. However, this study is not quantitative but is strictly qualitative. It is an attempt to reach general conclusions about the way witnesses approach the system, on the basis of their statements which are often perfunctory. As such, the comments below can be disagreed with as they are interpretations. In anticipation of such disagreement, it should be emphasized that the reader is encouraged to review the statements on their own and make own interpretations. Even if the interpretations are different from the following ones, such discrepancies are still valuable. Ultimately, when trying to make sense of an unresearched phenomenon, there is no such thing as too many perspectives.

Only one witness (witness 23) mentioned the system's obvious security-enhancing function. This was possibly because the research was conducted in one of the lower courts, which usually deal with low profile cases. Accordingly, one can hypothesize that witnesses were aware of the court's basic character and thus did not accentuate the security issues. Naturally, the hearings of low profile or trivial cases are not necessarily safer than high profile or serious ones. Ultimately, even the most seemingly trivial cases can fuel such strong emotions amongst the parties involved, that negative situations (in terms of security) can still occur.

In comparison, it is quite difficult to explain why the correction of time perception was not addressed at all by the interviewees. One hypothesis is that the witnesses probably did not notice the timer displayed on the television screen. As for the system's purpose as assistance for professionals in case of an appeal, there were 
some general and unclear statements hinting at the evidentiary potential of the recordings (witnesses $1,5,12,31,33,34$ ). Only one witness was more precise about the positives for professionals, when she remarked approvingly of the benefits of "not having to write down this much" (witness 32). From the perspective of lawyers, judges, and clerks, her statement was not precisely accurate. Ultimately, the clerk's job responsibility is still to record the events of the hearing. One can only speculate further why witness 32 answered the way she did and ignored the way courtrooms actually functioned. The easiest way to address this query is that the witness had a relatively low level of knowledge about courts and legal proceedings.

The issue of self-control is more complicated. Before addressing that issue, it seems reasonable to address the transparency issue first. The transparency-enhancing or signaling function seems to be present between the lines in some statements (e.g. witness 27). What should be emphasized, however, is that one witness criticized the system. His complaint was that as a witness, he was not authorized to obtain the recording of the hearing which he had participated in (witness 22). This raises questions about the limits of the transparency achieved through live camera feeds and audio-visual recordings of the hearings. What is also interesting is that one witness expressed a fear of the recording being published or distributed elsewhere than in court or amongst interested lawyers (witness 9). Needless to say, this concern is also entangled with the issue of transparency and its limits.

Additionally, it seems justified to argue that most witnesses were assessing live camera feeds and recordings of court hearings as a means of ex post control of the hearing. Many witnesses stated that it was good that hearings were recorded, but did not address the real-time display of the ongoing proceedings. There were exceptions where the statements were so general that it was hard to determine whether the witness was referring to a time during the hearing or after it (e.g. witness 16). Generally, it is possible to say that most witnesses were emphasizing that the cameras and recordings are used as a way to retain evidence and review the hearing afterwards. It is particularly interesting that many witnesses made critical statements, in the sense that they assumed the worst. Namely, they referred to the figure of a onesided judge who is rude and biased (e.g. witnesses 13, 21). There was one witness who had experience in going to court. He said that he had previously seen judges when there were no cameras, recordings, and television screens, and the situation had improved (witness 24). A possible explanation for the critical views on judges is the contemporary situation in Poland and the highly negative climate around judges and the justice system, which is to a certain extent created by political narratives and the so-called constitutional crisis in Poland (on that, see, for e.g., [20, 29, 45]). On the other hand, another source of such opinions is the generally understood legal consciousness of Poles, who seem to have been fairly negative about the law before the constitutional crisis, which started in 2015 [18].

Leaving this issue aside, it is peculiar that witnesses who are explicitly or implicitly critical of the judges are also positive about the system, because they seem to have neglected that the cameras do not capture the judge. Of course, judges are recorded but only auditorily. As one of the witnesses correctly noticed, "what is happening [not only what is said] is important" (witness 33). People in the courtroom can misbehave in ways that are not determinable with 
an audio recording. Gestures or facial expressions do not make a sound that can be recorded. The video is also needed in order to understand the majority of a person's behavior. From this perspective, speaking positively about a system which does not video-record judges is misguided. Naturally, this faulty judgment begs for an explanation. For instance, it appears that many witnesses were more focused on the cameras and not on the television screen close to them, so they could not see that the screen did not show the judge. This argument is justified because, as stated above, most of the witnesses' statements appear to emphasize the recording's ex post control of the participants' behavior during the hearing. They did not emphasize personal control in real time-did not remark on the live feed's presumable effect on self-control. Some witnesses also explained the system in relation to the other people in the courtroom, and not themselves. There is also a more trivial explanation for the witnesses' failure to notice that there is no camera which captures the judge. Possibly, the display's quality for some of the witnesses was so unclear, that they did not notice that the cameras do not capture everyone in the courtroom.

Returning to the issue of witnesses making worst-case assumptions, it should be emphasized that they also raised the possibility of lying before the court, or referred generally to "dirty play" taking place during the proceedings (e.g. witness 8 ). Some witnesses then explained the system as a "safe lock", referring to some of the worstcase scenarios in which witnesses lie, even though they have been informed of the punishments for perjury, or have taken the oath (sometimes required of witnesses in Poland), or behave in other questionable ways that can, if proven, lead to a form of legal responsibility. The recordings are evidence and the mere awareness of being recorded can reduce the probability of such misdeeds occurring (close to the selfcontrol function). What is striking is that the witnesses, on the one hand, are thinking of extreme situations and have such a strongly antagonistic vision of court proceedings, that their first thought, when asked about live camera feeds, was unfair court practices. On the other hand, the witnesses appeared to be oblivious to the fact that in their narrative the lies or other misdeeds actually occurred and the recordings were only a means to know what went wrong. Recordings appear to be treated only as a source of evidence, even though the system can also be a prevention device. Even though some statements seem to be close to recognizing the self-control function, most statements noticeably focus on the past, on the events that were recorded and not on the present, on situation that is recorded.

In comparison with this one-sidedness or inadequacy in some of the witnesses' opinions, many witnesses correctly addressed the important, potential flaw of the system. Namely, some witnesses suggested that live camera feeds can make people who are questioned nervous, embarrassed, stressed, or distracted (e.g. witnesses $14,20,25,28,30)$. There is not much to say other than to agree with them. Some witnesses facing their own reflection on the television screen, as captured by cameras, may have some problems with self-control (not only because of stress, but also because of other issues like an excessive focus on their looks). It is therefore necessary to emphasize, yet again, that the self-control function of live camera feeds on the television screen can only be realized for some people. Other people may become intimidated or distracted and start behaving in an unwanted or inappropriate 
manner, leading to a judge reacting negatively, which can in turn make the recipient of the negative reaction even more nervous and confused.

\section{Conclusion}

The system of displaying the feed from two cameras in the courtroom during hearings raises many questions, which can be addressed using different research methods. These issues can be listed in the following way: the system's influence on courtroom dynamics; the identities of those who are supposed to be the most influenced by the system, and those who are influenced in reality; the precise ways people are influenced by the system; the relationship between the system and procedural principles which should be followed during hearings; whether lawyers make use of the system's possibilities in their practice; the system's impact on public opinions and attitudes towards the justice system; or the reactions of professional lawyers, and judges, towards the system and the way they understand it. The system can be analyzed from many different perspectives, including specific categories of participants in a courtroom hearing. For instance, it is possible to think of the system as a means of ex post evidentiary control or real-time control. In addition to the focus on the witnesses' thoughts and how they are influenced by the system, one can and ultimately should address other participants in their own right, such as members of the general public, journalists, lawyers (legal representatives of the parties to a case), clerks, and, last but not least, judges. Even though judges are not captured by the cameras used in the system, the cameras and television screen can still be the subject of the judges' opinions and can influence their work. It is important to emphasize the latter, because additional, unintended consequences of the system are noticeable, which can be regarded as flaws. In particular, there are known instances of judges refusing to record a case hearing open to the public, even by reporters or journalists, on the grounds that the hearing was already recorded by the system or that the system could be easily switched on (e.g. [24, 33]). One can therefore say that there is much more to the main subject of this paper than the witnesses' perspective. However, because of the reasons stated above, this study focused only on witnesses' opinions.

This research demonstrated that witnesses offer simplified and one-dimensional perspectives of the system. They did not offer any multi-functional assessment of the live camera feeds. These perfunctory opinions deserve an explanation. Ultimately, the question is why people who are in the system's center are often oblivious to it, even when they are in small courtrooms and it would appear to be difficult to miss the system. At best, they offer basic ideas about the system, such as emphasizing ex post, evidentiary, function, and do not address its real-time influence. In other words, they only focus on the cameras and not the display on the television screen. Their behavior can be explained by the general characteristics of being a witness. For example, they could be stressed by being questioned in the courtroom for the first time and are trying to focus on the discussions of the other people involved. This could lead to them missing other details in the courtroom. Another reason is the way the statements were obtained from the witnesses, that is relatively short 
interviews conducted right after the witness left the courtroom. Nevertheless, the statements prove that there are details of a courtroom that are surprisingly difficult to notice for some people. The statements also show that these details potentially cause different reactions in witnesses, which are relevant for the judiciary's actions. The witnesses' reactions include being distracted and increasing stress, especially when the witness is related to a party to the case. Witnesses can also worry about how the recording will be used in the future and who will have access to it, especially when the witnesses did not have any prior knowledge about the system prior to their participation in the hearing. These and other possible consequences are just reasons why the system should be studied further. Further studies can also analyze whether the consequences were predicted before the system was implemented, and precisely which consequences were predicted, if any. Ultimately, this study was conducted in response to the lack of any studies on the system. Even though the above paragraphs provide some answers, they raise other questions. Consequently, this paper should be considered only as a first step to understand the system better.

Acknowledgements The paper was prepared within the research project „Dystans władzy na sali sądowej. Studium teoretyczno-empiryczne" ["Power Distance in the Courtroom. Theoretical and Empirical Study"] sponsored by the National Science Centre of Poland (Registration Number 2015/19/B/ HS5/00454). The authors declare their equal contribution in the creation of the paper. They would like also to thank here Anna Drwal and Jan Bazyli Klakla (who co-conducted described observations and interviews, as a realization of their Ph.D. student scholarship position within the mentioned project) and Jan Winczorek (who commented on the paper manuscript). Previous version of the paper was presented at the 19th International Roundtable for the Semiotics of Law (IRSL 2018) "Law and Arts in Crime Settings", May 23-May 25, 2018, Örebro, Sweden. The authors would like to take this opportunity to thank the organizers and participants for their sincere interest and inspiring comments.

Open Access This article is distributed under the terms of the Creative Commons Attribution 4.0 International License (http://creativecommons.org/licenses/by/4.0/), which permits unrestricted use, distribution, and reproduction in any medium, provided you give appropriate credit to the original author(s) and the source, provide a link to the Creative Commons license, and indicate if changes were made.

\section{References}

1. Alexander, Sherry L. 1999. Cameras in the Courtroom. In Encyclopedia of Television News, ed. Michael D. Murray, 32-34. Phoenix: Oryx.

2. Barber, Susanna. 1987. News Cameras in the Courtroom: A Free Press-Fair Trial Debate. Norwood: Ablex.

3. Bednarek, Grażyna Anna. 2014. Polish vs. American Courtroom Discourse: Inquisitorial and Adversarial Procedures of Witness Examination in Criminal Trials. Basingstoke: Palgrave Macmillan.

4. Bhatia, Vijay K., Christoph A. Hafner, Lindsay Miller, and Anne Wagner. 2012. Transparency, Power and Control in Legal Communication. In Transparency, Power and Control: Perspectives on Legal Communication, eds. Vijay K. Bhatia, Christoph A. Hafner, Lindsay Miller, and Anne Wagner, 1-10. Farnham: Ashgate.

5. Billitteri, Thomas J., ed. 2011. CQ Researcher 21(2) (Cameras in the Courtroom: Should TV be Allowed in Federal Courts?).

6. Borgida, Eugene, Kenneth G. DeBono, and Lee A. Buckman. 1990. Cameras in the Courtroom: The Effects of Media Coverage on Witness Testimony and Juror Perceptions. Law and Human Behavior 14(5): 489-509. 
7. Carter, Edward L. 2012. Supreme Court Oral Argument Video: A Review of Media Effects Research and Suggestions for Study. Brigham Young University Law Review 6: 1719-1757.

8. Cohn, Marjorie, and David Dow. 2002. Cameras in the Courtroom: Television and the Pursuit of Justice. Lanham: Rowman \& Littlefield.

9. Dahlberg, Leif. 2016. Spacing Law and Politics: The Constitution and Representation of the Juridical. Abingdon: Routledge.

10. Description of the subject of the contract-Digital System for Registering the Course of Court Hearings in Common Courts, https://www.ms.gov.pl/pl/ogloszenia/download,5914,4.html. Accessed 26 Mar 2019.

11. Dziemianowicz, Małgorzata. 2014. New Courtroom Technologies-Reality. A Judge's Perspective. In Biatystok Volumes on Law \& Culture: Volume 1: Court Culture: Contemporary Problems, ed. Anna Piszcz, 153-159. Białystok: Temida 2.

12. Ferraro, Guido. 2016. Experimental methods in semiotics. VERSUS - Quaderni di studi semiotici 122(2): 35-56.

13. Foucault, Michel. 1995. Discipline and Punish: The Birth of Prison. Trans. Alan Sheridan. New York: Vintage Books.

14. Fuoco, Robert J. 1982. The Prejudicial Effects of Cameras in the Courtroom. University of Richmond Law Review 16(4): 867-883.

15. Geis, Gilbert, and Robert E.L. Talley. 1957. Cameras in the Courtroom. Journal of Criminal Law and Criminology 47(5): 546-560.

16. Gerbner, George. n.d. Cameras in the Courtroom: A Proposal for Research. George Gerbner Archive, http://web.asc.upenn.edu/Gerbner/archive.aspx?sectionID=135\&packageID=799. Accessed 26 Mar 2019.

17. Golliher, Jeffrey Mark. 1982. On Discovering the Semiotic Organization of Experience: The Public Meanings and Private Meanings of Objects. In Semiotics 1980, eds. Michael Herzfeld and Margot D. Lenhart, 165-169. New York: Plenum Press.

18. Hertogh, Marc, and Marina Kurkchiyan. 2016. 'When Politics Comes into Play, Law is No Longer Law': Images of Collective Legal Consciousness in the UK, Poland and Bulgaria. International Journal of Law in Context 12(4): 404-419.

19. Hryncewicz-Lamber, Grażyna. 2013. The Computed-Aided Judiciary-How the Contemporary Technologies Change the Courtroom Design? In Universal Access in Human-Computer Interaction. Design Methods, Tools, and Interaction Techniques for eInclusion. 7th International Conference, UAHCI 2013, Held as Part of HCI International 2013, Las Vegas, NV, USA, July 21-26, 2013, Proceedings, Part I, eds. Constantine Stephanidis and Margherita Antona, 288-296. Berlin: Springer.

20. Koncewicz, Tomasz Tadeusz. 2017. Polish Judiciary in Times of Constitutional Reckoning. Of Fidelities, Doubts, Boats and... A Journey. Gdańskie Studia Prawnicze 38: 291-306.

21. Kozinski, Alex, and Robert Johnson. 2010. Of Cameras and Courtrooms. Fordham Intellectual Property, Media and Entertainment Law Journal 20(4): 1107-1134.

22. Lambert, Paul. 2012. Television Courtroom Broadcasting: Distraction Effects and Eye-tracking. Bristol: Intellect.

23. Lambert, Paul. 2013. Television Courtroom Broadcasting Effects: The Empirical Research and the Supreme Court Challenge. Lanham: University Press of America.

24. Lorenz Freimann. 2018. 22.12.2017—ta osoba jako sędzia półtorej godziny później rozpatrywała sprawę ZBIGNIEWA STONOGI. [22.12.2017-This Person, As a Judge, An Hour and a Half Later, Tried the Case of ZBIGNIEW STONOGA.]. YouTube video, 4:02. Posted January 2, Available at https://www.youtube.com/watch?v=rGv925SB1go. Accessed 26 Mar 2019.

25. Main Page-ReCourt Project: Digital Registration System of Court Proceedings in Common Courts; project realized for Polish Ministry of Justice, https://recourt.comarch.pl/web/portal/stron a-glowna. Accessed 26 Mar 2019.

26. Marder, Nancy S. 2012. The Conundrum of Cameras in the Courtroom. Arizona State Law Journal 44: 1489-1574.

27. Marrani, David. 2018. Space, Time, Justice: From Archaic Rituals to Contemporary Perspectives. Abingdon: Routledge.

28. Mason, Paul. 2000. Lights, Camera, Justice? Cameras in the Courtroom: An Outline of the Issues. Crime Prevention and Community Safety: An International Journal 2(3): 23-34.

29. Matczak, Marcin. 2018. Poland's Constitutional Crisis: Facts and Interpretations. Oxford: The Foundation for Law, Justice and Society. 
30. McDonell, Stephen. 2016. When China Began Streaming Trials Online. BBC News, Beijing, September 30, Available at https://www.bbc.com/news/blogs-china-blog-37515399. Accessed $26 \mathrm{Mar}$ 2019.

31. McElroy, Lisa T. 2012. Cameras at the Supreme Court: A Rhetorical Analysis. Brigham Young University Law Review 6: 1837-1899.

32. Minorczyk-Cichy, Aldona. 2012. W Katowicach i Gliwicach sądowe rozprawy już w oku kamery! [In Katowice and Gliwice court hearings are already in the eye of the camera!]. Dziennik Zachodni, October 29 and November 11, Available at https://dziennikzachodni.pl/w-katowicach-i-gliwicachsadowe-rozprawy-juz-w-oku-kamery-zobacz/ar/686905\#wiadomosci. Accessed 26 Mar 2019.

33. mo do. 2017. odcinek 34 - Sąd nie zna prawa? [episode 34 - The court does not know the law?]. YouTube video, 6:13. Posted February 11, Available at https://www.youtube.com/watch?v=03y4-_ QIjw. Accessed 26 Mar 2019.

34. naTemat.pl. 2015. Sąd okiem kamery [The court in the eye of the camera]. March 2, Available at https://natemat.pl/blogi/temidalight/135221,sad-okiem-kamery. Accessed 26 Mar 2019.

35. New York State Committee to Review Audio-Visual Coverage of Court Proceedings. 1997. An Open Courtroom: Cameras in New York Courts. New York: Fordham University Press.

36. NoweMEDIA Clips. 2012. E-PROTOKÓŁ: SYMULOWANA ROZPRAWA CZ. 1 [E-PROTOCOL: SIMULATED CASE HEARING PART I]. YouTube video, 8:30. Posted April 23, Available at https ://www.youtube.com/watch?v=HyMwohc4XaU. Accessed 26 Mar 2019.

37. Papandrea, Mary-Rose. 2012. Moving Beyond Cameras in the Courtroom: Technology, the Media, and the Supreme Court. Brigham Young University Law Review 6: 1901-1951.

38. Pearson, Charls. 1982. The Role of Scientific Paradigms in Empirical Semiotics. In Semiotics 1980, eds. Michael Herzfeld and Margot D. Lenhart, 395-405. New York: Plenum Press.

39. Polish Ministry of Justice-ReCourt Player, https://www.ms.gov.pl/pl/sady-w-internecie/e-protokol/ do-pobrania/. Accessed 26 Mar 2019.

40. PolsatNews. 2017. "Na salach sądowych potrzebne są kamery". Waldemar Żurek o poprawie kontroli pracy sędziów ["Cameras are needed in court rooms." Waldemar Żurek on improving the control of judges' work]. September 27, Available at http://www.polsatnews.pl/wiadomosc/2017-09-27/ czy-polskie-sady-potrzebuja-rewolucji-dorotagawrylukzaprasza-o-2100/. Accessed 26 Mar 2019.

41. SIPS TV. 2014. Infostrada 2013-Prezentacja systemu ReCourt (Pracownicy Ministerstwa Sprawiedliwości) [Infostrada 2013-Presentation of the ReCourt system (Employees of the Ministry of Justice)]. YouTube video, 34:15. Posted January 2, Available at https://www.youtube.com/ watch? $\mathrm{v}=\mathrm{OsBb} 2-\mathrm{xqgP} 8$. Accessed 26 Mar 2019.

42. Supreme Court's Committee for the Study of Cameras in the Trial Courts. 2010. Appendix to Final Reports and Recommendations. Supreme Court State of South Dakota.

43. Supreme Court's Committee for the Study of Cameras in the Trial Courts. 2010. Final Report and Recommendations. Supreme Court State of South Dakota.

44. Supreme People's Court Monitor. 2016. Cameras in the Chinese courts. July 22, Available at https ://supremepeoplescourtmonitor.com/2016/07/22/cameras-in-the-chinese-courts/. Accessed 26 Mar 2019.

45. Szuleka, Małgorzata, Marcin Wolny, and Marcin Szwed. 2016. The Constitutional Crisis in Poland 2015-2016. Trans. Joanna Smętek. Warsaw: Helsinki Foundation for Human Rights.

46. Task Force Committee on Cameras in the Courtroom. 2010. Updated Report on Cameras in the Courtroom. Irvine: American College of Trial Lawyers.

47. Tilley, Cristina Carmody. 2014. I Am a Camera: Scrutinizing the Assumption that Cameras in the Courtroom Furnish Public Value by Operating as a Proxy for the Public. Journal of Constitutional Law 16(3): 697-738.

48. Valverde, Mariana. 2015. Chronotopes of Law: Jurisdiction, Scale and Governance. Abingdon: Routledge.

49. West, Sonja R. 2012. The Monster in the Courtroom. Brigham Young University Law Review 6: 1953-1988.

50. Włodkowska, Katarzyna. 2014. Na salach sądowych dźwięk i obraz będą nagrywane [In the courtrooms, sound and picture will be recorded]. Wyborcza.pl, Trójmiasto, May 19, Available at http:// trojmiasto.wyborcza.pl/trojmiasto/1,35612,15979674,Na_salach_sadowych_dzwiek_i_obraz_beda_ nagrywane.html?disableRedirects=true. Accessed 26 Mar 2019.

51. Wykop.pl. Sędziowie nie zgadzają się na nagrywanie rozpraw sądowych [The Judges Disagree with the Recording of Court Hearings]. Available at https://www.wykop.pl/link/1802004/sedziowie-niezgadzaja-sie-na-nagrywanie-rozpraw-sadowych/. Accessed 26 Mar 2019. 
52. Youm, Kyu Ho. 2012. Cameras in the Courtroom in the Twenty-First Century: The U.S. Supreme Court Learning From Abroad? Brigham Young University Law Review 6: 1989-2031.

Publisher's Note Springer Nature remains neutral with regard to jurisdictional claims in published maps and institutional affiliations. 